\title{
Bioaerosol exposure by farm type in Korea
}

\author{
Eun Young Kim ${ }^{1, A-D \oplus *}$, Jiyoung Han ${ }^{2, A-D \oplus *}$, Yun-Keun Lee ${ }^{3, B \oplus}$, Won Kim ${ }^{3, C \oplus}$, Soo-Jin Lee ${ }^{2, E-F \oplus}$ \\ 1 Institute of Occupation Environment, Korean Workers' Compensation and Welfare Service, Republic of Korea (South) \\ 2 Department of Occupational and Environmental Medicine, Hanyang University College of Medicine, Republic of Korea \\ (South) \\ ${ }^{3}$ Wonjin Institute for Occupational and Environmental Health, Republic of Korea (South) \\ A - Research concept and design, B - Collection and/or assembly of data, C - Data analysis and interpretation, \\ $D$ - Writing the article, $E$ - Critical revision of the article, $F$ - Final approval of the article \\ * these authors contributed equally to this work
}

Eun Young Kim, Jiyoung Han, Yun-Keun Lee, Won Kim, Soo-Jin Lee. Bioaerosol Exposure By farm Type in Korea. Ann Agric Environ Med. 2022; 29(1): 38-43. doi: 10.26444/aaem/144759

\begin{abstract}
Introduction and Objective. Bioaerosols exist in almost every environment and are known to be risk factors for a variety of diseases. Agricultural work involves high exposure to bioaerosols and its workplace concentrations affect the surrounding areas. The study evaluates bioaerosol concentrations in agricultural workplaces and residential areas according to farm type.

Materials and method. In 2013-2015, a total of 381 samples were collected for endotoxin and microbial testing from three farm types: open field, greenhouse, and livestock facilities. Endotoxins were measured using a 37-mm glass fire filter connected to an air pump calibrated to 2 LPM. Microorganisms were measured using a gelatin filter and impaction (singlestage Andersen sampler).

Results. The concentration of endotoxins and microorganisms at the livestock facilities was significantly higher than in the open fields and greenhouses $(p<0.05)$. Among the livestock farms, the concentrations of endotoxins and gram-negative bacteria were highest at hog farms, and the concentrations of total bacteria and fungi were the highest in poultry houses. In both greenhouses and livestock facilities, the concentrations of bioaerosols were higher in the workplace than in a nearby residential area, and the difference in concentration was significantly greater in the case of livestock facilities.

Conclusions. The concentrations of bioaerosols in agricultural workplaces and nearby residential areas were higher than in the control and general areas. Therefore, measures should be taken to prevent exposure to bioaerosols at agricultural workplaces and their vicinities.
\end{abstract}

\section{Key words}

workplace, endotoxin, agriculture, bioaerosol, residential area

\section{INTRODUCTION}

Bioaerosols are airborne particles of microbial, plant and animal origin and constitute a substantial part of organic dust [1]. Specifically, bioaerosols include fungal conidia and hyphae, bacterial vegetative cells and spores, endotoxins, glucans, mycotoxins or high-molecular-weight allergens, and organic dusts in general, composed of or derived from biological matter [2]. They are known to be risk factors for a variety of diseases, including infectious diseases, hypersensitivity, asthma, allergy, and cancer [3], of which infectious and respiratory diseases are the most common [4]. Infectious diseases are caused by bacteria, fungi, and viruses through the transmission of infectious agents by direct or indirect contact, airborne and vector-borne transmission [5, 6]. Impairment of lung function and respiratory symptoms are common mild conditions to severe chronic respiratory diseases [4]. Cancer can be caused by oncogenic viruses and non-viral biological carcinogens, such as mycotoxins (e.g. ochratoxin A) [4]. For those reasons, interest in bioaerosol exposure in both occupational and residential indoor environments has increased during the past few decades.

\footnotetext{
Address for correspondence: Soo-Jin Lee, Department of Occupational and Environmental Medicine, Hanyang University College of Medicine, Seoul, Republic of Korea (South)

E-mail: sjlee@hanyang.ac.kr

Received: 01.05.2021; accepted: 10.12.2021; first published:
}

Farms are workplaces with particularly high exposure to bioaerosols and agricultural activities also therefore increase the likelihood of exposure to bioaerosols [7]. Farms typically hold a large number of animals, such as poultry, swine, and cattle, mainly in indoor settings and at high densities. The variety of possible sources associated with those conditions produces complex mixtures of microorganisms within the bioaerosols emitted from farms [8-12]. This dynamic microbial composition places farm workers and nearby residents at high risk for health issues, such as accelerated declines in lung function, changes in blood pressure, nasal inflammation, secretory immunity, infectious diseases, as well as dermatological and gastrointestinal problems $[13,14]$.

Currently in Korean agriculture, a rapid increase in the use of concentrated animal feeding operations in the livestock industry to grow swine, cattle, poultry, etc., in confined buildings and greenhouses has increased the probability that farm workers will be exposed to organic dust. Furthermore, most farmers live adjacent to their workplaces, therefore organic dust generated in the workplace could also contaminate residential spaces.

\section{OBJECTIVE}

The aim of this study was to evaluate the concentration of organic dust, including endotoxins, in workplaces and 
adjacent residential areas on farms, including greenhouse and livestock farms, in rural areas of South Korea.

\section{MATERIALS AND METHOD}

Study subjects. In 201-2015, samples from 21 kinds of crops were tested for endotoxins ( $n=381)$, total bacteria $(n=363)$, and fungi $(n=346)$ (Tab. 1). Farms were divided into three types: open field, greenhouse, and livestock facilities, with the latter category subdivided by animal: poultry, swine, and cattle. The open field farms grew crops such as grapes, green beans, and rice in a natural environment without the aid of any kind of enclosed artificial facility. Greenhouse farms grew most of their crops, mainly leafy vegetables, leeks, Chinese cabbage, peppers, cucumbers, tomatoes, and watermelons, within an enclosed structure to maintain optimal growing conditions. Livestock facilities grew poultry, swine, and cattle, with many of them having places within the workspace, such as manure storage areas, that had a very high probability of breeding microorganisms. When a farming residential area was adjacent to a workspace, such as a barn, the same items and conditions measured in the workspace were also measured in the residential area (living room, bedroom, kitchen), to evaluate whether organic dust generated in the workplace also contaminated the residential area.

Sampling method. Measurement of area samples was conducted to confirm microbial and endotoxin levels in the workplaces, and personal samples collected in the farmer's breathing zone to assess the exposure levels faced by individual farmers while carrying out their work activities. For the personal measurements, bioaerosol was sampled on sterilized gelatin filters (Cat. No. 225-9551, SKC Inc., USA) with Button aerosol sampler (Cat. No. 225-360, SKC Inc., USA) at a flow rate of 4 LPM using pumps (AirChek XR5000, Cat. No. 210-5001, SKC Inc., USA). The area samples were measured using Biostage single-stage impactor (model QuickTake 30 Biostage, Cat. No. 228-9530K, SKC Inc., USA) at a flow rate of 28.3 LPM. The endotoxin was sampled on sterilized glass fibre filters at a flow rate of 2 LPM using pumps (model AirChek XR5000, Cat. No. 210-5001, SKC Inc., USA). Endotoxins were measured in a two-stage cassette through a glass fibre filter sterilized at $180^{\circ} \mathrm{C}$ for two hours during the entire agricultural work period. Local and individual endotoxin samples were acquired in the same manner. The flow rate of all measuring instruments was calibrated before and after each measurement, and the average value was applied. To measure the concentration of microbial and endotoxin levels of the general residential environment, indoor pollution was evaluated by the same method in the living room, bedroom, and kitchen. To compare the concentrations of microorganisms and endotoxins in the air, a control group (area sampling) was selected at a distance of about $100 \mathrm{~m}$ from the farm, and measured simultaneously with the exposure group performing the agricultural work. Temperature and humidity were measured at all locations using direct-acting equipment (7545, TSI Inc., USA).

The number of samples by farm type was as follows: from open field farms, 4 personal, 20 workplace, and 7 control samples were taken; from greenhouses, 32 personal, 159 workplace, 15 residential area, and 42 control samples were taken; from the livestock facilities, 21 workplace, 9 residential area, and 5 control samples were taken from poultry farms, 8 workplace, 5 residential area, and 1 control samples were taken; from swine farms; and 48 workplace and 5 control samples were collected; from cattle farms. The total number of samples was 907 from greenhouse farms, 390 from livestock facilities, and 117 from open field farms.

Analysis method. Each gelatin filter was placed in a sterile tube with a $10 \mathrm{ml}$ extraction solution $(0.1 \%$ Pepton $+0.01 \%$ Tween 80 ) immediately after measurement and stored in a refrigerator until analysis. The extraction was performed by shaking the tube for five minutes in a vortex mixer. After extraction, a $500 \mathrm{uL}$ aliquot from the suspension was spread on tryptic soy agar, MacConkey agar, and Sabouraud Dextrose + Chloramphenicol Agar to cultivate bacteria, gram-negative bacteria, and fungi, respectively. In addition, the extract solution was diluted as necessary $\left(10^{-2}, 10^{-3}\right)$. The spread agar plates for personal samples and impactor agar plates for area samples were incubated at $37 \pm 0.5^{\circ} \mathrm{C}$ for 24 , 48,72 , and 96 hours, and microbial cultures were counted as colonies. The concentration of airborne bacteria and fungi $\left(\mathrm{CFU} / \mathrm{m}^{3}\right)$ was calculated by dividing the counted colonies by the volume of sampled air.

For endotoxin extraction, a glass fibre filter was placed in a sterile pryogen-free with $10 \mathrm{ml}$ LAL water. The extraction was performed by shaking the tube for $15 \mathrm{~min}$ in a vortex mixer and then subjected to ultrasonication for one hour. The extracts were centrifuged at 2,500 r.pm. for $25 \mathrm{~min}$, and only the supernatant was analyzed. Endotoxin activity was quantitated using a Turbidimetric-Kinetic Limulus amoebocyte lysate (LAL) assay (BioWhittaker, Walkersville, MD, USA), and its concentration expressed as endotoxin units (EU) per cubic meter $\left(\mathrm{EU} / \mathrm{m}^{3}\right)$.

Statistical analysis. Data were analyzed using SPSS 18.0. T-testing, Mann-Whitney U testing, and Kruskal-Wallis H testing were performed to compare the concentrations on each type of farm, and to compare concentrations between the individual and local samples. All tests were two-sided, and $\mathrm{p}$-values $<0.05$ were considered statistically significant.

Ethical Considerations. The study was approved by the Institutional Review Board (IRB) of Hanyang University (Approval No. HYI-13-068-1). All study participants were fully informed about the purpose and procedure of the study and provided written consent.

\section{RESULTS}

Table 1 shows the number of samples for each type of farm. Each farm type had subgroup samples: personal, workplace, residential area, and control area, and all samples were tested for endotoxins, total bacteria, gram-negative bacteria, and fungi. Table 2 shows the bioaerosol concentration, temperature, and relative humidity for each type of farm. Endotoxins, total bacteria, gram-negative bacteria, and fungi were measured. The concentrations at livestock facilities were significantly higher than those at open field and greenhouse facilities $(\mathrm{p}<0.05)$. In particular, gram-negative bacteria, which are known to contribute directly to the production of endotoxins, had an average concentration at livestock facilities that was about three times higher than that in 
Table 1. Sampling scheme and number of samples by farm type

\begin{tabular}{|c|c|c|c|c|c|c|c|c|c|}
\hline \multirow{2}{*}{ Farm type } & & \multicolumn{2}{|r|}{ Personal } & \multicolumn{2}{|r|}{ Workplace } & \multicolumn{2}{|r|}{ Residential area } & \multicolumn{2}{|r|}{ Control } \\
\hline & & $N$ & $\begin{array}{l}\text { Sampling time, min. } \\
\text { Mean (range) }\end{array}$ & $N$ & $\begin{array}{l}\text { Sampling time, min. } \\
\text { Mean (range) }\end{array}$ & $N$ & $\begin{array}{l}\text { Sampling time, min. } \\
\text { Mean (range) }\end{array}$ & $N$ & $\begin{array}{c}\text { Sampling time, min. } \\
\text { Mean (range) }\end{array}$ \\
\hline Open field & & 4 & 55 (16-93) & 20 & $232(15-308)$ & & - & 7 & 169 (19-299) \\
\hline Greenhouse & & 32 & $253(109-364)$ & 159 & $207(108-394)$ & 15 & $238(180-320)$ & 42 & $210(108-394)$ \\
\hline \multirow{3}{*}{ Live-stock } & Poultry & & - & 21 & $192(169-218)$ & 9 & 181 (162-197) & 5 & $186(182-193)$ \\
\hline & Swine & & - & 8 & $216(209-224)$ & 5 & $207(202-211)$ & 1 & 213 \\
\hline & Cattle & & - & 48 & $216(54-312)$ & & - & 5 & $229(166-317)$ \\
\hline Total & & & 36 & & 256 & & 29 & & 60 \\
\hline
\end{tabular}

Table 2. Airborne concentrations of endotoxins and microorganisms and the values of microclimate parameters by farm type

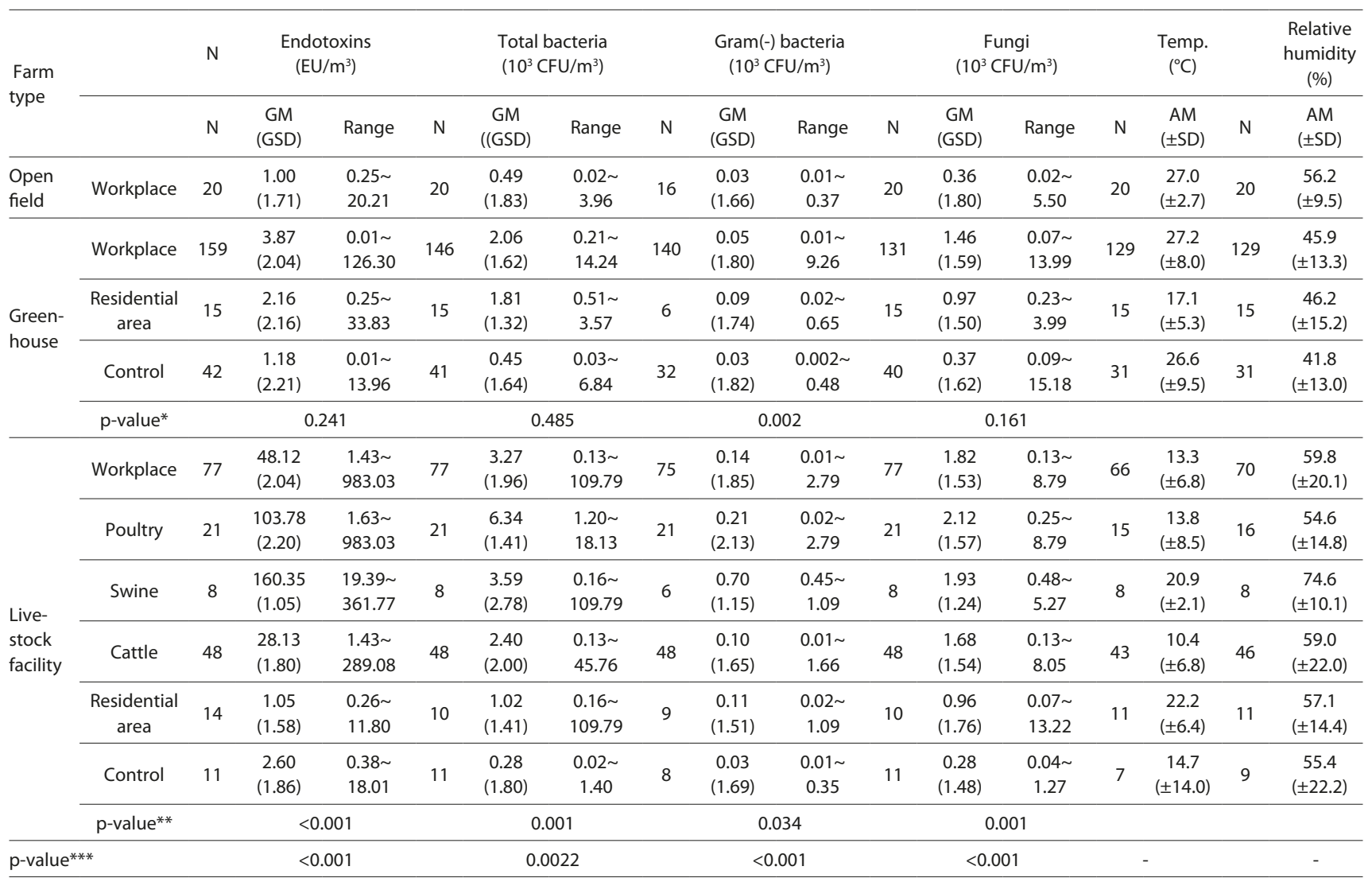

* $p$-value comparing workplace and residential area samples in greenhouse determined using the t-test, Mann-Whitney test ** p-value comparing workplace and residential area samples in livestock facilities determined using the Mann-Whitney test *** $\mathrm{p}$-value* between open field, greenhouse, and livestock facility samples determined using the Kruskal-Wallis test

greenhouses. Among the different types of livestock facilities, the geometric mean concentration of endotoxins was the highest at hog farms $\left(160.35 \mathrm{EU} / \mathrm{m}^{3}\right)$, followed by poultry houses $\left(103 \mathrm{EU} / \mathrm{m}^{3}\right)$ and cowsheds $\left(28 \mathrm{EU} / \mathrm{m}^{3}\right)$ (Tab. 2). The concentrations of total bacteria and gram-negative bacteria, but not fungi, were higher than those at poultry houses and cowsheds. In both the greenhouse and livestock facilities, the concentration of endotoxins in the workplace and residential areas was the highest, followed by total bacteria, gram-negative bacteria and fungi, respectively. The concentrations of endotoxins and microorganisms in the residential areas near greenhouses were higher than in the control areas. The difference in concentrations of endotoxins, total bacteria, and fungi was not statistically significant. The concentration of gram-negative bacteria in greenhouse workplaces was significantly lower than that in residential areas. The concentrations of endotoxins, total bacteria, gram-negative bacteria, and fungi in the workplaces of livestock facilities were all significantly higher than those in residential areas. The temperature of the open field and greenhouse farms was about $27^{\circ} \mathrm{C}$, and relative humidity $-46-56 \%$. The temperature of the poultry houses was $13.8^{\circ} \mathrm{C}$, and relative humidity $-54.6 \%$. In the cowsheds, the temperature was $10.4^{\circ} \mathrm{C}$, and relative humidity $-59.0 \%$. At the hog farms, the temperature was $20.9^{\circ} \mathrm{C}$, and relative humidity $-74.6 \%$.

Table 3 compares the concentrations in the personal area samples from greenhouses. The concentrations of endotoxins and microorganisms were measured in samples taken from each of the people working in the greenhouse, the workplaces 
Table 3. Comparison of endotoxin and microorganism concentrations between personal and area samples in greenhouses

\begin{tabular}{|c|c|c|c|c|c|c|c|c|c|c|c|}
\hline \multirow{2}{*}{ Sample type } & \multirow{2}{*}{$\mathrm{N}$} & \multicolumn{2}{|c|}{$\begin{array}{l}\text { Endotoxins } \\
\left(\mathrm{EU} / \mathrm{m}^{3}\right)\end{array}$} & \multicolumn{2}{|c|}{$\begin{array}{l}\text { Total bacteria } \\
\left(10^{3} \mathrm{CFU} / \mathrm{m}^{3}\right)\end{array}$} & \multicolumn{2}{|c|}{$\begin{array}{l}\text { Gram(-) bacteria } \\
\left(10^{3} \mathrm{CFU} / \mathrm{m}^{3}\right)\end{array}$} & \multicolumn{2}{|c|}{$\begin{array}{c}\text { Fungi } \\
\left(10^{3} \mathrm{CFU} / \mathrm{m}^{3}\right)\end{array}$} & \multirow{2}{*}{$\begin{array}{c}\text { Temp. } \\
\left({ }^{\circ} \mathrm{C}\right) \\
\begin{array}{c}\text { AM } \\
( \pm S D)\end{array}\end{array}$} & \multirow{2}{*}{$\begin{array}{c}\begin{array}{r}\text { Relative } \\
\text { humidity } \\
(\%)\end{array} \\
\begin{array}{c}\text { AM } \\
( \pm S D)\end{array}\end{array}$} \\
\hline & & $\begin{array}{c}\mathrm{GM} \\
(\mathrm{GSD})\end{array}$ & Range & $\begin{array}{c}\mathrm{GM} \\
(\mathrm{GSD})\end{array}$ & Range & $\begin{array}{c}\mathrm{GM} \\
(\mathrm{GSD})\end{array}$ & Range & $\begin{array}{c}\mathrm{GM} \\
(\mathrm{GSD})\end{array}$ & Range & & \\
\hline Personal & 32 & $\begin{array}{l}10.66 \\
(2.38)\end{array}$ & $\begin{array}{c}0.01 \sim \\
623.00\end{array}$ & $\begin{array}{c}1.78 \\
(2.32)\end{array}$ & $\begin{array}{l}0.06 \sim \\
86.04\end{array}$ & $\begin{array}{c}0.13 \\
(2.09)\end{array}$ & $\begin{array}{c}0.01 \sim \\
3.35\end{array}$ & $\begin{array}{c}1.69 \\
(2.05)\end{array}$ & $\begin{array}{l}0.07 \sim \\
38.76\end{array}$ & $\begin{array}{l}32.0 \\
(3.4)\end{array}$ & $\begin{array}{l}49.6 \\
(9.5)\end{array}$ \\
\hline Control & 42 & $\begin{array}{c}1.18 \\
(2.21)\end{array}$ & $\begin{array}{l}0.01 \sim \\
13.96\end{array}$ & $\begin{array}{c}0.45 \\
(1.64)\end{array}$ & $\begin{array}{c}0.03 \sim ~ \\
6.84\end{array}$ & $\begin{array}{c}0.03 \\
(1.82)\end{array}$ & $\begin{array}{l}\text { ND } \\
0.48\end{array}$ & $\begin{array}{c}0.37 \\
(1.62)\end{array}$ & $\begin{array}{l}0.09 \sim \\
15.18\end{array}$ & $\begin{array}{l}26.6 \\
(9.5)\end{array}$ & $\begin{array}{c}41.8 \\
(13.0)\end{array}$ \\
\hline p-value* & & & & & & & & & & - & - \\
\hline
\end{tabular}

*p-value comparing personal and area samples by Mann-Whitney test

Table 4. Spearman rank correlation of different hazard factors and workplace conditions

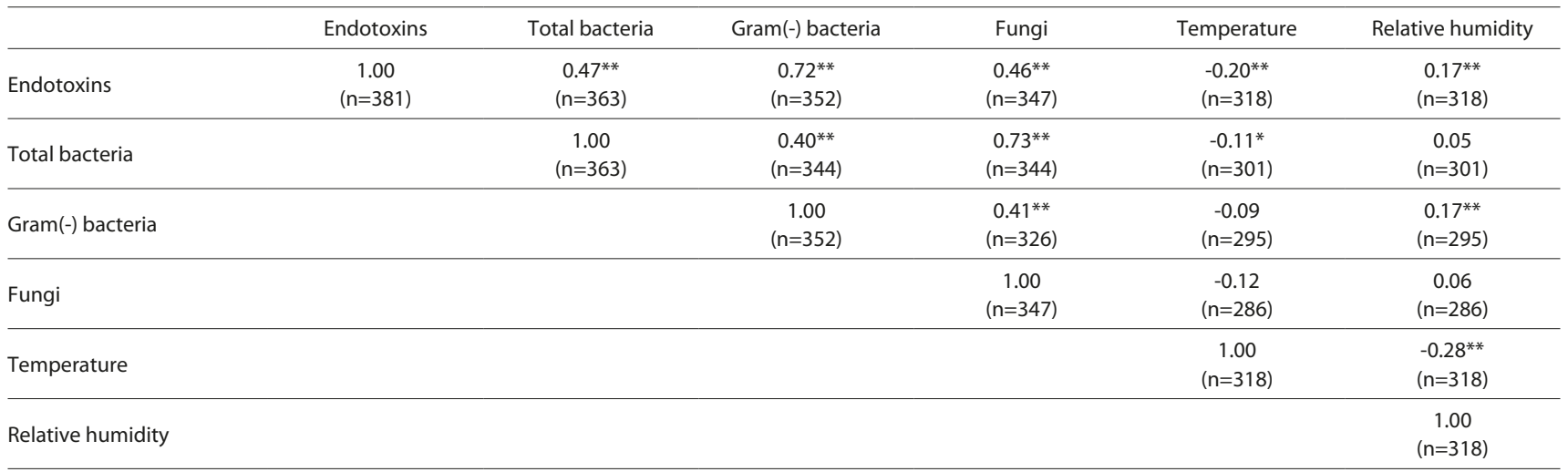

${ }^{* *} p<0.01,{ }^{*} p<0.05$

and control areas. The geometric mean concentrations of endotoxins and gram-negative bacteria in the personal samples were significantly higher than those from the workplace samples. The average temperatures measured with each sample were between $26.6^{\circ} \mathrm{C}-32.0^{\circ} \mathrm{C}$, and relative humidity between $41.8 \%-49.6 \%$.

There was a relationship between the concentration of bioaerosols and the surrounding environment (Tab. 4). Total bacteria showed a moderate correlation with fungi $(r=0.73)$, while gram-negative bacteria showed a moderate correlation with endotoxins $(r=0.72)$. In addition, the correlation coefficient between endotoxins and total bacteria and fungi was $0.46-0.47$, indicating a moderate correlation. On the other hand, temperature showed a weak negative correlation with the levels of endotoxins and total bacteria, while relative humidity showed a weak positive correlation with endotoxins and gram-negative bacteria.

\section{DISCUSSION}

In rural or agricultural environments, health problems caused by bioaerosols of pollen, grains, animals, and animal wastes have been reported for decades $[15,16,17]$. Recently, health problems caused by endotoxins have emerged with the most commonly reported being respiratory problems (e.g., rhinitis, asthma, asthma-like syndrome, bronchitis, and COPD). It is known that when the level of endotoxins in the air exceeds $30 \mathrm{EU} / \mathrm{m}^{3}$, toxicity begins to appear. Endotoxin exposure at the level of $100 \mathrm{EU} / \mathrm{m}^{3}$ can cause respiratory tract inflammation, and exposure to $2,000 \mathrm{EU} / \mathrm{m}^{3}$ could lead to severe pneumonia symptoms $[18,19,20]$.

In order to prevent endotoxin-induced illness, some countries, including The Netherlands, but not Korea, have established exposure limits in the workplace or the general environment. The Netherlands recommends an exposure limit for the general population of $30 \mathrm{EU} / \mathrm{m}^{3}$, based on applying a safety factor of three to the occupational limit of $90 \mathrm{EU} / \mathrm{m}^{3}$ [8]. The Occupational Health and Safety (OHS) research centre, one of the leading research centres in Canada, and the Institut de recherche Robert-Sauvé en santé et en sécurité du travail (IRSST), on the other hand, provides action levels based on the respiratory symptoms of exposed workers that require improvement of the working environment. When respiratory symptoms are reported, the action level is 10 times the background level, and in the absence of respiratory symptoms, the action level is 30 times the background level.

In South Korea, in the working environments of most industries, including manufacturing and agriculture, there are no established exposure limits for microorganisms. Instead, the 'Indoor Air Quality Control Act' of the Ministry of the Environment and 'Office Air Management Guideline' of the Ministry of Employment and Labour, suggest a microbial exposure standard for offices and some vulnerable living environments. For example, in multi-use facilities, such as medical institutions, postpartum care centres, nursing homes, day care centres and all offices, the total bacteria in the indoor air should be less than $800 \mathrm{CFU} / \mathrm{m}^{3}$ [21]. To determine the approximate exposure level it is necessary 
to compare the endotoxin and microbial concentrations measured in the current study with the exposure limits given by some countries or relevant authorities. The average concentration of endotoxins reported here was lower than the Dutch exposure limits, except on hog farms and poultry houses, where endotoxin concentrations were $160.35 \mathrm{EU} / \mathrm{m}^{3}$ and $103.78 \mathrm{EU} / \mathrm{m}^{3}$, respectively, therby exceeding the Dutch workplace exposure limit of $90 \mathrm{EU} / \mathrm{m}^{3}$. In 2013, the endotoxin concentration measured by Kim et al. on 10 hog farms in Korea was $109.35 \mathrm{EU} / \mathrm{m}^{3}$ [22], and in a study of $14 \mathrm{hog}$ farms by Yoo et al. in 2003 [23], the endotoxin concentration was $190.55 \mathrm{EU} / \mathrm{m}^{3}$, results which are similar to those of the current study.

Previous studies have shown that airway inflammation may occur at endotoxin levels below $90 \mathrm{EU} / \mathrm{m}^{3}$ and the positive significant reaction of the respiratory tract occurred when the geometric mean endotoxin concentration reached $15.4 \mathrm{EU} / \mathrm{m}^{3}$ [24]. Endotoxin exposure as low as 10$200 \mathrm{EU} / \mathrm{m}^{3}$ can also negatively affect the respiratory system [25]. Thus, the work environments of hog farms and poultry houses measured in the current study are harmful and could cause acute respiratory symptoms in exposed workers. Proper ventilation and the use of respiratory protective equipment is necessary to protect the workers.

Although the endotoxin concentrations on open field farms, greenhouse farms, and cowsheds were lower than those at hog farms and poultry houses, even those low concentrations might adversely affect health. In a study in New Zealand, plywood workers exposed to $23 \mathrm{EU} / \mathrm{m}^{3}$ of endotoxins had significantly more attacks of shortness of breath with wheezing than unexposed controls [26]. In addition, another study showed that the mean FEV1 on spirometry decreased among potato processing workers exposed to $56 \mathrm{EU} / \mathrm{m}^{3}$ of endotoxins [27], and a further study found a mean decrease in the FEV1 of textile yarn workers exposed to endotoxin levels of $0.64 \mathrm{EU} / \mathrm{m}^{3}$ [28]. A systematic review also concluded that respiratory health effects from exposure to low levels of airborne endotoxin $\left(<100 \mathrm{EU} / \mathrm{m}^{3}\right)$ seem plausible [29]. Therefore, it is necessary to manage endotoxin exposure in all agricultural workplaces and nearby residential areas. In addition, further studies should be conducted on the health effects of exposure to low levels of endotoxins.

The average concentration of total bacteria on all types of farms, although not the control areas, was higher than the exposure limits set by ACGIH [30] in Canada [31], and all microbial concentrations in the livestock facilities were higher than in the open field and greenhouse facilities, with hog farms again having the highest levels. Canada is proposing an additional 1,000 $\mathrm{CFU} / \mathrm{m}^{3}$ for gram-negative bacteria. The concentrations of gram-negative bacteria found in the current study in all the workplaces and control areas were lower than the proposed Canadian limits. In the livestock facilities, which had a higher concentration of gram-negative bacteria than the other areas, the highest concentration was on the hog farms $\left(0.73 \times 10^{3} \mathrm{CFU} / \mathrm{m}^{3}\right)$, followed by the poultry houses $\left(0.63 \times 10^{3} \mathrm{CFU} / \mathrm{m}^{3}\right)$ and cowsheds $\left(0.20 \times 10^{3} \mathrm{CFU} / \mathrm{m}^{3}\right)$.

A previous study in Korea reported a bacterial concentrations of $2.7 \times 10^{5} \mathrm{CFU} / \mathrm{m}^{3}$ and $5.6 \times 10^{7} \mathrm{CFU} / \mathrm{m}^{3}$ from hog farms and poultry houses, respectively [32], and also reported fungal concentrations of $4.9 \times 10^{3}$ and $2.1 \times 10^{3}$ $\mathrm{CFU} / \mathrm{m}^{3}$, respectively. The remarkable difference in microbial concentrations between studies at similar work sites is presumed to be the result of the influence of temperature, humidity, and workplace conditions at the time of measurement. For example, in livestock workplaces, airborne microbial concentrations have been reported to be high during certain tasks, such as weighing, animal movement, and faecal-cleaning tasks [33]. Therefore, the current study, which did not take samples during such tasks, reports relatively low concentrations of microorganisms and fungi. When comparing concentrations of microorganisms in a workplace, it is necessary to take into consideration the working conditions and the season, along with environmental conditions, such as temperature and humidity, at the time of measurement.

The concentrations of organic dust in the residential areas of farmers were generally lower than those in the workplaces. However, the endotoxin and microbial concentrations were still about three times higher than in the control areas. Furthermore, the bacterial and fungal exposure levels in those residential areas exceeded the criteria set by both the 'Indoor Air Quality Control Act' of the Ministry of Environment $\left(800 \mathrm{CFU} / \mathrm{m}^{3}\right.$ for total bacteria, $500 \mathrm{CFU} / \mathrm{m}^{3}$ for fungi) [21], and the levels found in residential and office spaces in typical urban areas in South Korea. In a study of 69 offices, Kim et al. (2008), reported total bacterial and fungal concentrations of $426 \mathrm{CFU} / \mathrm{m}^{3}$ and $234 \mathrm{CFU} / \mathrm{m}^{3}$, respectively [34].

The high levels of microorganisms found in the residential areas of farmers in the current study presumably occurred through propagation from the contaminated workplaces near the residential area. The workplaces of many farms in South Korea are located within $100 \mathrm{~m}$ of their associated residential area. Another possible reason is that most Korean farmers enter their residential areas wearing the same clothes they wore during work. For greenhouses and livestock facilities that have relatively high concentrations of microorganisms, rest areas should be located as far away as possible from the workplace. In addition, protective measures, such as the installation of ventilation equipment, will be to change the behaviour of the workers, e. g. taking off their work clothes and showering before entering residential areas.

There are some limitations to consider when interpreting the results of this study. Firstly, the samples were collected at different times of the year, therefore the effects of environmental conditions (temperature, humidity, wind speed, etc.,) and seasonal factors could not be controlled. Secondly, the microbiological and endotoxin levels of some farms, especially the livestock facilities, might be underestimated because the measurement protocols did not adequately cover certain tasks, such as weighing, animal movement, and faecal-cleaning tasks which are known to generate high concentrations of endotoxins.

\section{CONCLUSIONS}

The measured levels of endotoxins in the workplaces at hog farms and poultry houses exceeded exposure limits, indicating that the health of farmers working under those conditions could be threatened. The total bacterial concentration also exceeded the exposure limit at all sites where it was measured. In addition, the concentrations of personal samples, which more closely reflect worker exposure, were higher than those of the area samples, which imply that 
the actual exposure levels of farmers might differ, even within the same workplace, depending on the tasks performed and the degree of work activity. Interestingly, exposure levels in residential and rest areas were significantly higher than in the control areas, although they were lower than in the workplaces. This was presumably caused by contamination from bioaerosols generated in the workplace.

In order to protect farmers from health hazards caused by bioaerosols, appropriate measures should be taken to reduce them in the workplace; countermeasures against pollution in residential and rest areas should also be considered.

\section{Acknowledgements}

This work was carried out with the support of "Cooperative Research Program for Agriculture Science and Technology Development (Project No. PJ01426903)" Rural Development Administration, Republic of Korea.

\section{REFERENCES}

1. Xuezheng MA, et al. Spatial distribution of atmospheric bioaerosols in Beijing, Hangzhou and Wuhan, China. Aerobiologia. 2021; 37(1): 155-170. https://doi.org/10.1007/s10453-020-09680-6

2. Oppliger A. Advancing the science of bioaerosol exposure assessment. Ann Occupat Hygiene. 2014; 58(6): 661-663. https://doi.org/10.1093/ annhyg/meu042

3. Mbareche H, Morawska L, Duchaine C. On the interpretation of bioaerosol exposure measurements and impacts on health. J Air Waste Management Assoc. 2019; 69(7): 789-804. https://doi.org/10.1080/10 962247.2019.1587552

4. Douwes J, et al. Bioaerosol health effects and exposure assessment: progress and prospects. Ann Occupat Hygiene. 2003; 47(3): 187-200. https://doi.org/10.1093/annhyg/meg032

5. Mbareche H, Morawska L, Duchaine C. On the interpretation of bioaerosol exposure measurements and impacts on health. J Air Waste Management Assoc. 2019; 69(7): 789-804. https://doi.org/10.1080/10 962247.2019.1587552

6. Chretien Jean-Paul, et al. Global climate anomalies and potential infectious disease risks: 2014-2015. PLoS currents. 2015,7. https://doi org/10.1371/currents.outbreaks.95fbc4a8fb4695e049baabfc2fc8289f

7. Fritschi L, et al. The estimated prevalence of exposure to asthmagens in the Australian workforce, 2014. BMC pulmonary medicine. 2016; 16(1): 1-11. https://doi.org/10.1186/s12890-016-0212-6

8. Douglas $\mathrm{P}$, et al. A systematic review of the public health risks of bioaerosols from intensive farming. Int J Hygiene Environ Health. 2018; 221(2): 134-173. https://doi.org/10.1016/j.ijheh.2017.10.019

9. Gilbert Y, Duchaine C. Bioaerosols in industrial environments: a review. Can J Civil Engineering. 2009; 36(12): 1873-1886. https://doi. org/10.1139/L09-117

10. Just $\mathrm{N}$, et al. Bacterial diversity characterization of bioaerosols from cage-housed and floor-housed poultry operations. Environ Res. 2011; 111(4): 492-498. https://doi.org/10.1016/j.envres.2011.01.009

11. Lanier $C$, et al. Airborne molds and mycotoxins associated with handling of corn silage and oilseed cakes in agricultural environment. Atmospheric Environ. 2010; 44(16): 1980-1986. https://doi.org/10.1016/j. atmosenv.2010.02.040

12. Létourneau V, et al. Human pathogens and tetracycline-resistant bacteria in bioaerosols of swine confinement buildings and in nasal flora of hog producers. Int J Hygiene Environ Health. 2010; 213(6): 444-449. https://doi.org/10.1016/j.ijheh.2010.09.008

13. O'Connor AM, et al. The association between proximity to animal feeding operations and community health: a systematic review. PloS one. 2010; 5(3): e9530. https://doi.org/10.1371/journal.pone.0009530

14. Schiffman SS, et al. Symptomatic effects of exposure to diluted air sampled from a swine confinement atmosphere on healthy human subjects. Environ Health Perspectives. 2005; 113(5): 567-576. https:// doi.org/10.1289/ehp.6814

15. Chen Ruey-Yu, et al. Fungal bioaerosol exposure and its effects on the health of mushroom and vegetable farm workers in Taiwan. Aerosol Air Quality Res. 2017; 17(8): 2064-2075. https://doi.org/10.4209/ aaqr.2016.09.0401

16. Liebers V, Brüning T, Raulf M. Occupational endotoxin exposure and health effects. Arch Toxicol. 2020; 94(11): 3629-3644. https://doi: 10.1007/s00204-020-02905-0

17. Poole Jill A, Debra J. Romberger. Immunological and inflammatory responses to organic dust in agriculture. Curr Opinion Allergy Clin Immunol. 2012; 12(2): 126-132. https:// doi: 10.1097/ ACI.0b013e3283511d0e

18. Milton DK, et al. Endotoxin exposure-response in a fiberglass manufacturing facility. Am J Industrial Med. 1996; 29(1): 3-13. https://doi.org/10.1002/(SICI)1097-0274(199601)29:1<3::AIDAJIM2>3.0.CO;2-V

19. Latza U, Oldenburg M, Baur X. Endotoxin exposure and respiratory symptoms in the cotton textile industry. Arch Environ Health: An International J. 2004; 59(10): 519-525. https://doi. org/10.1080/00039890409605168

20. Schierl R, et al. Endotoxin concentration in modern animal houses in southern Bavaria. Ann Agric Environ Med. 2007; 14(1): 129-136.

21. Ministry of Environment of Korea, Indoor Air Quality Control Act, Act No. 14486, Dec. 27, 2016.

22. Kim Hyoung Ah, et al. Relationship between endotoxin level of in swine farm dust and cellular immunity of husbandry workers. J Korean Soci Occup Environ Hygiene. 2013; 23(4): 393-401.

23. Yoo DH, et al. Concentration of dust and endotoxin in swine confinement building. J Korean Soc Occup Environ Hygiene. 2003; 13(1): 45-52.

24. Cyprowski M, Sobala W, Buczyńska A, Szadkowska-Stańczyk I. Endotoxin exposure and changes in short-term pulmonary function among sewage workers. Int J Occup Med Environ Health. 2015; 28(5): 803-811. https://doi.org/10.13075/ijomeh.1896.00460

25. Kennedy SM, et al. Cotton dust and endotoxin exposure-response relationships in cotton textile workers. Am Rev Respiratory Dis. 1987; 135(1): 194-200.

26. Fransman W, et al. Respiratory symptoms and occupational exposures in New Zealand plywood mill workers. Ann Occup Hygiene. 2003; 47(4): 287-295. https://doi.org/10.1093/annhyg/meg046

27. ZockJP, et al. Acute lung function changes and low endotoxin exposures in the potato processing industry. Am J Industrial Med. 1998; 33(4): 384-391. https://doi.org/10.1002/(sici)1097-0274(199804)33:4<384::aidajim9>3.0.co; $2-\mathrm{u}$

28. Kateman E, et al. Relationship of airborne microorganisms with the lung function and leucocyte levels of workers with a history of humidifier fever. Scand J Work Environ Health. 1990: 428-433. https:// doi.org/10.5271/sjweh.1764

29. Farokhi A, Heederik D, Lidwien AM Smit. Respiratory health effects of exposure to low levels of airborne endotoxin-a systematic review. Environ Health. 2018; 17(1): 1-20. https://doi.org/10.1186/s12940-0180360-7

30. ACGIH. Guidelines for the assessment of bioaerosols in the indoor environment. Cincinnati, OH: American Conference of Governmental Industrial Hygienists. 1989.

31. IRSST. Bioaerosols in the Workplace: Evaluation, Control and Prevention Guide. Occupational Health and Safety Research Institute Robert Sauve. 2001.

32. Kim,Young-Hwan, et al. Evaluation of environmental circumstance within swine and chicken houses in South Korea for the production of safe and hygienic animal food products. Food Sci Animal Resources. 2008; 28(5): 623-628. https://doi.org/10.5851/kosfa.2008.28.5.623

33. Lee Yun-Keun, et al. Concentrations of Airborne Microorganisms and Endotoxins in Duck Houses. J Environ Health Sci. 2010; 36(3): 191-198. https://doi.org/10.5668/JEHS.2010.36.3.191

34. Kim Ki Youn, et al. Profile of airborne microorganisms distributed in general offices. J Korean Soci Occup Environ Hygiene. 2008; 18(1): 11-19. 